\title{
Penyelidikan KLB Keracunan Makanan di Desa Banjaroyo Kabupaten Kulon Progo
}

\author{
Food Intoxication Outbreak Investigation in Banjaroyo Village
}

\author{
Fatma Nuraisyah \\ Fakultas Kesehatan Masyarakat, Universitas Ahmad Dahlan, Yogyakarta, Indonesia \\ (fatma.nuraisyah@ikm.uad.ac.id)
}

\begin{abstract}
ABSTRAK
Berdasarkan hasil laporan, sebanyak tujuh orang warga berobat ke puskesmas secara bersamaan dengan keluhan/gejala yang sama, mengalami diare, perut sakit, pusing, mulas, lemas setelah mengonsumsi makanan. Tujuan penelitian untuk menelusuri gejala dan penyebab dugaan keracunan setelah mengonsumsi makanan yang dihidangkan pada acara peresmian Microhidro 16 Mei 2014 di Desa Banjaroyo. Penelitian ini menggunakan rancangan kasus-kontrol. Kasus adalah orang yang mengonsumsi hidangan yang mengalami gejala diare, nyeri perut, dan mual. Kontrol adalah orang yang tidak mengalami gejala seperti kasus setelah mengonsumsi hidangan dengan matching umur dan jenis kelamin. Subjek adalah responden yang mengonsumsi makanan dan diwawancarai. Sampel makanan dikirim ke laboratorium untuk dilakukan pemeriksaan. Jumlah kasus awal 170 orang. Gejala yang paling banyak dirasakan penderita adalah diare $(73,16 \%)$, nyeri perut $(67,10 \%)$. Tipe kurva epid adalah common source. Penularan penyakit secara common source dan masa inkubasi adalah 1 sampai 16 jam. Hasil pemasangan untuk uji analitik didapatkan 60 pasang kasus dan kontrol. Jenis makanan yang diduga menjadi penyebab keracunan makanan adalah sambal krecek $(\mathrm{OR}=18,5 ; 95 \% \mathrm{CI}=1,42-230,25)$, dan ayam bacem $(\mathrm{OR}=22,03 ; 95 \%$ $\mathrm{CI}=2,32-208,42)$. Hal ini diduga positif Staphylococcus yang mengkontaminasi makanan sehingga orang yang makan mengalami keracunan. Keracunan makanan yang telah terjadi penyebabnya diduga bakteri Staphylococcus. Kemungkinan selama pemanasan ulang dan penyimpanan menjadi dugaan bahwa makanan terkontaminasi. Kata Kunci: Keracunan makanan, kasus-kontrol, diare
\end{abstract}

\begin{abstract}
Based on the report, there are seven people consulted at the health center with the same complaints/symptoms, experiencing diarrhea, abdominal pain, dizziness, heartburn, weakness after consuming food. The purpose of this research is to search for the symptoms and suspected causes of poisoning after consuming food served in celebration event Microhidro May 16, 2014 in Banjaroyo village. This research use case-control study. Cases were people who consumed food served during the ceremony who experienced symptoms of diarrhea, abdominal pain, and nausea. . Controls were people with no symptomps after consumed food served with age and sex matching. Subjects were interviewed regarding food items consumed. Left-over food items were sent to a laboratory for testing. There were 170 cases. Majority had diarrhea (73\%) and abdominal pain (67\%). Incubation periods ranged from 1 to 16 hours. The epidemic curve was that of a common source outbreak. Sixty cases and 60 controls were included in the case-control study. Food items associated with illness were fried chicken (OR:10.47;95\% CI 2.3446.70) and sambal krecek (OR:6.88; 95\% CI 1.38-34.29); these were positive for Staphylococcus. Foods were stored at room temperature with some persons taking food home to share with their families, some of who also got sick. This outbreak was probably caused by food contaminated with Staphylococcus. The foods could ha ve been contaminated during preparation and storage.
\end{abstract}

Keywords: Food intoxication diseases, case-control, diarrhea 


\section{PENDAHULUAN}

Suatu penyakit keracunan dicurigai apabila sejumlah orang telah makan bersama kemudian secara bersamaan juga mengalami sakit. Menemukan bagian makanan mana yang menjadi sumber penularan penyakit sulit dilakukan. Semua orang yang menyantap makanan harus dikelompokkan berdasarkan komponen makanan yang disantap. Namun, semakin sulit bila makanan tersebut juga dikonsumsi dibeberapa tempat yang berbeda dan waktu makan tidak bersamaan. ${ }^{1}$ Kejadian Luar Biasa (KLB) keracunan pangan atau dikenal dengan istilah "Foodborne Disease Outbreak" sebagai suatu kejadian dimana terdapat dua orang atau lebih yang menderita sakit setelah mengonsumsi pangan yang secara epidemiologi terbukti sebagai sumber penularan. ${ }^{2,3}$

Kejadian Luar Biasa (KLB) yang pernah terjadi setelah mengonsumsi makanan kemungkinan besar terkontaminasi oleh bakteri, beberapa penelitian terkait KLB keracunan makanan yang dilakukan di beberapa negara yaitu kasus keracunan diakibatkan makanan yang dikonsumsi mengandung Vibrio Cholera, penelitian ini dilakukan di Morocco, ${ }^{4}$ penyebab keracunan akibat makanan yang mengandung Staphylaccocus Aureus di Swiss, ${ }^{5}$ dan kasus KLB keracunan yang diakibatkan makanan yang dikonsumsi mengandung Staphycoccal di Umbria (Italia). ${ }^{6}$ Diperkirakan setiap tahun KLB keracunan makanan akibat dari kontaminasi bakteri mencapai 60 juta anak mengalami sakit termasuk 50 ribu anak mati di Asia Selatan. ${ }^{7}$ Selanjutnya, insiden keracunan makanan mengalami peningkatan 2 kali lipat dari 61 menjadi 135 wabah di 34 provinsi selama tahun 20152016 di Indonesia. ${ }^{8}$ Berawal dari 7 pasien yang berobat dengan gejala (diare, perut sakit, pusing, mulas, lemas) dan tempat kejadian yang sama, maka Kepala Puskesmas Kalibawang menduga bahwa telah terjadi keracunan makanan Jumat, 17 Mei 2014 jam 08.00 WIB di Desa Banjaroyo, terkait kejadian tersebut petugas surveilans puskesmas melaporkan secara lisan via telepon pada hari Jumat, 17 Mei jam 09.00 WIB ke petugas surveilans Dinas Kesehatan.

Sebelum ke lapangan tim petugas gerak cepat KLB Dinkes Kulon Progo mengklarifikasi ulang kejadian tersebut untuk memastikan waktu kejadian dugaan keracunan makanan pada tanggal
17 Mei 2014, jumlah orang yang sakit berasal dari acara yang sama dan jumlah kasus sementara 7 orang. Penelitian ini dilakukan untuk mengetahui diagnosa penyakit atau keracunan dari kasus-kasus yang dilaporkan, memastikan kebenaran adanya kejadian luar biasa keracunan makanan, menggambarkan KLB yang terjadi menurut variabel orang, dan waktu, mengidentifikasi sumber keracunan (reservoir) dan penyebabnya (causative agent).

\section{BAHAN DAN METODE}

Desain penelitian ini ialah analitik observasional dengan rancangan kasus kontrol. Kasus adalah orang yang mengalami salah satu atau lebih gejala diare, sakit perut, mulas, kejang perut yang disertai pusing, lemas, dan gejala lainnya setelah mengonsumsi hidangan yang disajikan pada acara peresmian Mikrohidro yang dilaksanakan oleh warga setempat tanggal 16 Mei 2014 di Desa Banjaroyo. Kontrol adalah orang yang tidak sakit setelah mengonsumsi hidangan yang disajikan di acara tersebut. Variabel yang diteliti meliputi gejala klinis yang timbul dan jenis makanan yang dimakan oleh kelompok kasus dan kelompok kontrol pada waktu yang sama saat menyantap makanan. Pelacakan dilakukan di desa Banjaroyo, Kecamatan Kalibawang sebagai tempat kejadian dugaan keracunan makanan dan catering sebagai tempat pengolahan makanan. Analisis yang digunakan yaitu univariat, bivariat menggunakan uji chi-square, attributable risk dan analisis multivariat menggunakan uji logistik berganda. Berdasarkan informasi yang diperoleh dari tim seksi acara, undangan yang disebarkan sebanyak 204 ekslamplar yang berhasil diwawancarai sebanyak 230 orang dimana 60 orang tidak mengalami sakit dan 170 orang mengalami sakit. Populasi berisiko tidak dapat diketahui dengan pasti seberapa besar yang datang dan makan makanan yang dihidangkan saat acara peresmian. Data yang telah dianalisis selanjutnya disajikan dalam bentuk tabel dan narasi. Protokol penelitian ini telah disetujui oleh komite etik dari Politeknik Kesehatan Kemenkes Yogyakarta No. LB.01.01/KE-02/ XXVII/687/2018. Instrumen dalam penelitian ini menggunakan kuesioner serta pengukuran kualitas makanan di BLK Yogyakarta. 


\section{HASIL}

Berdasarkan hasil investigasi lapangan diperoleh bahwa jumlah undangan yang telah terdistribusikan sebanyak 204 orang, pemesanan makanan catering sebanyak 300 kotak dan beberapa jenis hidangan makanan lokal dari masyarakat setempat. Berdasarkan definisi operasional kasus yang ditetapkan, jumlah orang yang berhasil diwawancarai sebanyak 230 orang diantaranya 170 sakit dan 60 orang tidak sakit.

Berdasarkan Tabel 1 menunjukkan bahwa gejala yang banyak dirasakan responden adalah diare $(73,16 \%)$, dari gejala yang dirasakan paling banyak, selanjutnya ditetapkan diagnosa banding penyakit. Sejala yang dirasakan responden dugaan sementara penyebab keracunan makanan acara di Desa Banjaroyo adalah Bacillus Cereus, C. Perfringen dan Staphylaccocus Aureus. Berdasarkan dari hasil investigasi penderita yang diobati sebanyak 117 penderita dengan gejala utama diare, mulas, dan pusing, semua pasien boleh pulang (rawat jalan) dan dilaporkan sekitar 8 orang yang berobat ke bidan setempat. Sampel makanan catering dan beberapa snack dikirim ke BLK Yogyakarta.

Setelah dilakukan pemasangan menurut jenis kelamin dan umur responden yang mengalami keracunan makanan yang paling tinggi pada umur 21-45 tahun sebanyak 29 orang (48,33\%) dan menurut jenis kelamin adalah laki-laki sebanyak 41 orang $(68,33 \%)$. Responden yang mengalami sakit paling tinggi setelah mengonsumsi makanan yang dihidangkan dalam acara tersebut adalah laki-laki sebanyak 41 orang $(68,33 \%)$ sebelumnya dilakukan matching menurut umur dan jenis kelamin. ${ }^{2,4}$

\begin{tabular}{|c|c|c|}
\hline Gejala & $\mathbf{n}$ & $\%$ \\
\hline BAB lebih dari 3x (Diare) & 169 & 73,16 \\
\hline Nyeri Perut (Kram)/sakit perut & 155 & 67,10 \\
\hline Mual & 113 & 48,92 \\
\hline Kejang Perut & 82 & 35,50 \\
\hline Lemas & 66 & 28,57 \\
\hline Pusing & 57 & 24,68 \\
\hline Mules & 39 & 16,88 \\
\hline Panas & 15 & 6,49 \\
\hline Tremor & 11 & 4,76 \\
\hline Muntah & 5 & 2,16 \\
\hline
\end{tabular}

Sumber: Data Primer, 2014
Berdasarkan kurva epidemik menunjukkan bahwa masa inkubasi terpendek \pm 1 jam dan masa inkubasi terpanjang \pm 16 jam setelah mengonsumsi hidangan yang disuguhkan dalam acara peletakan batu pertama di Dusun Semawung tanggal 16 Mei. Gejala pertama mulai muncul adalah 1 jam setelah makan, puncaknya adalah pada interval 10 jam sedangkan kasus terakhir muncul pada interval waktu 16 jam. Berdasarkan grafik epidemik menunjukkan bahwa adanya jarak interval waktu dari jam mengonsumsi makanan dengan munculnya gejala pertama memberikan indikator kemungkinan kontaminasi toksin (racun) dari bakteri pada makanan, ketahanan tubuh masing-masing orang berbeda serta jumlah makanan pada makanan yang dimakan (Gambar 1). Kurva epidemik tersebut menunjukkan cara penularan pada peristiwa keracunan pasca acara tersebut adalah common source artinya penularan keracunan makanan bersumber dari satu sumber yang berlangsung dalam waktu yang cepat. ${ }^{2}$

Keracunan makanan yang terjadi kemungkinan adanya keterkaitan erat dengan menu yang dimakan sebelumnya. Menu yang disuguhkan dalam dus yaitu nasi, ayam, gudeg, sambel krecek, telur. Snack berasal dari produksi warga setempat terdiri dari kacang, pisang, buah naga, geblek, tiwul, tempe koro/benguk, nasi jagung, gula semut, bajingan, dan klepon. Mengetahui kemungkinan risiko pada masing-masing makanan dengan menghitung attack rate perjenis makanan dan untuk mengetahui asosiasi menggunakan odds ratio pada studi kasus kontrol.

Hasil yang diperoleh bahwa attributable risk yang paling tinggi menurut jenis olahan makanan catering adalah nasi $(50,6 \%)$. Artinya, jika nasi tidak dikonsumsi oleh populasi yang berisiko kemungkinan akan terjadi penurunan proporsi kasus sebesar 50,6\% (Tabel 2). Sedangkan hasil yang diperoleh berdasarkan Tabel 3 menunjukkan bahwa attributable risk yang paling tinggi menurut jenis olahan makanan lokal adalah pisang rebus dan kacang rebus. Artinya, jika pisang rebus atau kacang rebus tidak dikonsumsi oleh populasi yang berisiko kemungkinan akan terjadi penurunan proporsi kasus sebesar 3,4\% atau 2,3\%. Nilai OR yang paling tinggi adalah gudeg sebesar 38 ( $p=0,000$;$\mathrm{CI}=5,21-276,76)$ artinya orang yang makan gudeg lebih rentan berisiko mengalami sakit sebesar 38 


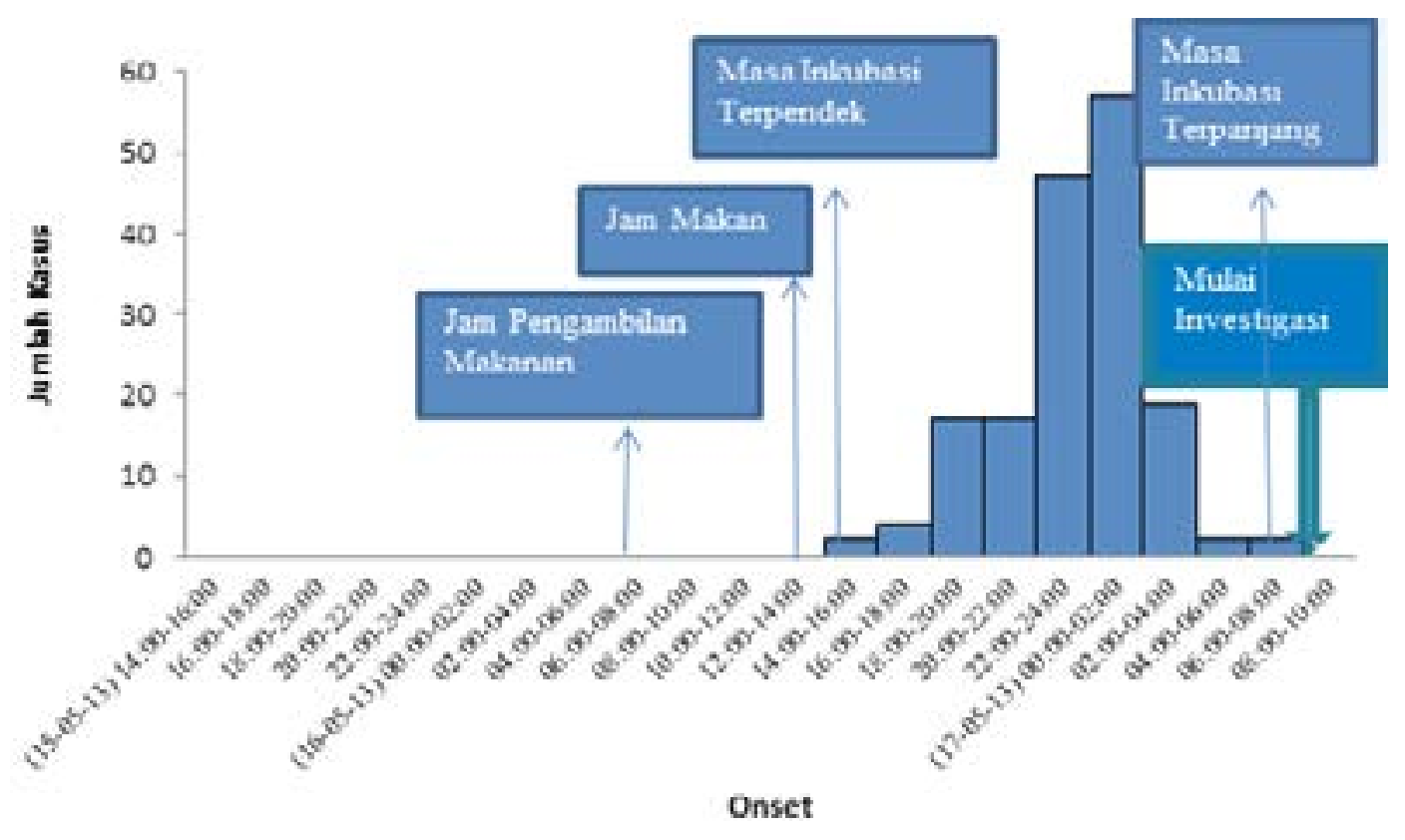

Gambar 1. Kurva Epidemik Keracunan Makanan di Desa Banjaroyo

Tabel 2. Attributable Risk Keracunan Makanan Menurut Jenis Makanan Olahan Catering Makanan

\begin{tabular}{|c|c|c|c|c|c|}
\hline \multirow{2}{*}{ Jenis Makanan } & \multirow{2}{*}{ Konsumsi } & \multicolumn{2}{|c|}{ Status Sakit } & \multirow{2}{*}{ Jumlah } & \multirow{2}{*}{$\begin{array}{c}\text { Attributable } \\
\text { Risk }\end{array}$} \\
\hline & & Tidak Sakit & Sakit & & \\
\hline \multirow[t]{2}{*}{ Nasi } & Tidak makan & 47 & 4 & 120 & 50,6 \\
\hline & Makan & 13 & 56 & & \\
\hline \multirow[t]{2}{*}{ Ayam goreng bacem } & Tidak makan & 47 & 8 & 120 & 23,5 \\
\hline & Makan & 13 & 52 & & \\
\hline \multirow[t]{2}{*}{ Gudeg } & Tidak makan & 48 & 11 & 120 & 17,8 \\
\hline & Makan & 12 & 49 & & \\
\hline \multirow[t]{2}{*}{ Sambal krecek } & Tidak makan & 47 & 14 & 120 & 11,8 \\
\hline & Makan & 13 & 46 & & \\
\hline \multirow[t]{2}{*}{ Telur bacem } & Tidak makan & 46 & 12 & 120 & 13,14 \\
\hline & Makan & 14 & 48 & & \\
\hline
\end{tabular}

Sumber: Data Primer, 2014

kali dibandingkan dengan orang yang tidak makan gudeg (Tabel 4). Berdasarkan Tabel 5 dapat dijelaskan bahwa sambal krecek $(\mathrm{OR}=6,7)$ artinya orang yang makan sambal krecek berisiko mengalami sakit sebesar 7 kali daripada orang yang tidak makan sambal krecek ( $p=0,018 ; \mathrm{CI}=1,3-34,3)$, ayam bacem $(\mathrm{OR}=10,4)$ artinya orang yang makan ayam bacem berisiko mengalami sakit sebesar 10 kali daripada orang yang tidak makan ayam bacem $(p=0,002 ; \mathrm{CI}=2,34-46,70)$. Hasil pemeriksaan laboratorium spesimen makanan catering yaitu Staphylococcus, Aeromonas Sobri, Jamur/Yeast, Pseudomonas Aeruginosa, dan Enterobacter
Aerogenes, sedangkan makanan lokal mengandung bakteri patogen yaitu Staphylococcus.

Berdasarkan hasil wawancara dengan penjamah makanan diperoleh informasi bahwa semua yang telah dilakukan dari pembelian bahan mentah, penyimpanan bahan mentah, pengolahan bahan mentah, penyimpanan makanan siap saji, pemanasan makanan serta pengepakan makanan telah dilakukan sesuai prosedur yang baik dan benar. Pengolahan makanan dilakukan seluruh penjamah makanan dalam keadaan sehat serta kondisi dapur bersih. Waktu pelaksanaan diolahnya bahan makanan dimulai pada jam 15.00 WIB tang- 
gal 15 Mei sampai selesai lalu didiamkan dalam suhu kamar dan wadah makanan tersebut ditutup. Makanan dihangatkan kembali pada jam 04.00 WIB tanggal 16 Mei, makanan yang telah hangat lalu dikemas ke kotak kemudian makanan kotak tersebut diambil oleh pihak penyelenggara pada jam 08.00 WIB tanggal 16 Mei 2014. Makanan tersebut diambil dan dibawa ketempat acara dengan kendaraan tertutup.

Hasil wawancara dari pihak penyelenggara dikatakan bahwa nasi kotak tersebut diambil jam 08.00 WIB dan diletakkan diatas meja dengan ruangan terbuka. Kemudian dikonsumsi jam 12.00 WIB. Matching dilakukan menurut umur dan jenis kelamin di dalam suatu metode penelitian case-control agar dapat mengendalikan efek jenis kelamin dan umur terhadap suatu penyakit, mengetahui efek penyebab terhadap kejadian suatu penyakit dan memaksimalkan kontrol jika jumlah kasus lebih dari kontrol. ${ }^{4}$ Penelitian ini, matching menurut jenis kelamin dan umur dilakukan berdasarkan tidak diketahui dengan pasti jumlah orang yang membawa dan mengonsumsi makanan yang dihidangkan, jumlah kasus lebih banyak daripada jumlah kontrol, agar mendapatkan perbandingan seimbang 1:1 menjadi kasus 60 orang dan kontrol 60 orang.

Berdasarkan hasil investigasi menurut masa inkubasi, gejala yang dirasakan oleh penderita dan grafik kurva epidemik serta jenis makanan yang dicurigai menyebabkan keracunan makanan dapat dilihat dari hasil nilai uji multivariat adalah ayam bacem $(\mathrm{OR}=10,4)$, dan sambel krecek $(\mathrm{OR}=6,7)$, serta makanan tersebut diduga terkontaminasi oleh bakteri Staphylococcus. Hasil penemuan epidemiologi sama dengan hasil laboratorium yang diperoleh bahwa positif Staphylococcus, berdasarkan jenis makanan dari catering dan lokal.

\section{PEMBAHASAN}

Staphylococcus merupakan bakteri berbentuk bulat (coccus) yang bila diamati di bawah mikroskop tampak berpasangan, membentuk rantai pendek, atau membentuk kelompok yang tam-

Tabel 3. Attributable Risk Keracunan Makanan Menurut Jenis Makanan Olahan Lokal

\begin{tabular}{|c|c|c|c|c|c|}
\hline \multirow{2}{*}{ Jenis Makanan } & \multirow{2}{*}{ Konsumsi } & \multicolumn{2}{|c|}{ Status Sakit } & \multirow{2}{*}{ Jumlah } & \multirow{2}{*}{$\begin{array}{c}\text { Attributable } \\
\text { Risk }\end{array}$} \\
\hline & & Tidak Sakit & Sakit & & \\
\hline \multirow[t]{2}{*}{ Kacang rebus } & Tidak makan & 38 & 21 & 120 & 3,2 \\
\hline & Makan & 22 & 39 & & \\
\hline \multirow[t]{2}{*}{ Pisang rebus } & Tidak makan & 47 & 31 & 120 & 3,4 \\
\hline & Makan & 13 & 29 & & \\
\hline \multirow[t]{2}{*}{ Buah naga } & Tidak makan & 46 & 40 & 120 & 1,6 \\
\hline & Makan & 14 & 20 & & \\
\hline \multirow[t]{2}{*}{ Geblek } & Tidak makan & 42 & 29 & 120 & 2,5 \\
\hline & Makan & 18 & 31 & & \\
\hline \multirow[t]{2}{*}{ Tempe koro } & Tidak makan & 44 & 37 & 120 & 1,7 \\
\hline & Makan & 16 & 23 & & \\
\hline \multirow[t]{2}{*}{ Tempe Benguk } & Tidak makan & 48 & 40 & 120 & 2 \\
\hline & Makan & 12 & 20 & & \\
\hline \multirow[t]{2}{*}{ Tiwul } & Tidak makan & 34 & 34 & 120 & 1 \\
\hline & Makan & 26 & 26 & & \\
\hline \multirow[t]{2}{*}{ Nasi Jagung } & Tidak makan & 33 & 39 & 120 & 0,7 \\
\hline & Makan & 27 & 21 & & \\
\hline \multirow[t]{2}{*}{ Bajingan } & Tidak makan & 46 & 44 & 120 & 1,2 \\
\hline & Makan & 14 & 16 & & \\
\hline \multirow[t]{2}{*}{ Klepon } & Tidak makan & 39 & 31 & 120 & 1,7 \\
\hline & Makan & 21 & 29 & & \\
\hline \multirow[t]{2}{*}{ Gula Semut } & Tidak makan & 37 & 25 & 120 & 2,3 \\
\hline & Makan & 23 & 35 & & \\
\hline \multirow[t]{2}{*}{ Air Mineral } & Tidak minum & 50 & 41 & 120 & 3,3 \\
\hline & Minum & 10 & 60 & & \\
\hline
\end{tabular}

Sumber: Data Primer, 2014 
Tabel 4. Odds Ratio Keracunan Makanan Menurut Jenis Makanan Olahan

\begin{tabular}{|c|c|c|c|c|c|c|c|}
\hline \multirow{2}{*}{ Jenis Makanan } & \multirow{2}{*}{ Konsumsi } & \multicolumn{2}{|c|}{ Status } & \multirow{2}{*}{ Jumlah } & \multirow{2}{*}{ OR } & \multirow{2}{*}{ p value } & \multirow{2}{*}{ CI } \\
\hline & & Tidak Sakit & Sakit & & & & \\
\hline \multicolumn{8}{|l|}{ Catering } \\
\hline \multirow[t]{2}{*}{ Nasi } & Tidak makan & 47 & 4 & 120 & 0 & 0 & 0 \\
\hline & Makan & 13 & 56 & & & & \\
\hline \multirow[t]{2}{*}{ Ayam goreng bacem } & Tidak makan & 47 & 8 & 120 & 20,5 & 0,000 & $4,2-72,7$ \\
\hline & Makan & 13 & 52 & & & & \\
\hline \multirow[t]{2}{*}{ Gudeg } & Tidak makan & 48 & 11 & 120 & 38 & 0,000 & $5,2-276,7$ \\
\hline & Makan & 12 & 49 & & & & \\
\hline \multirow[t]{2}{*}{ Sambal krecek } & Tidak makan & 47 & 14 & 120 & 17,5 & 0,000 & $4,2-72,7$ \\
\hline & Makan & 13 & 46 & & & & \\
\hline \multirow[t]{2}{*}{ Telur bacem } & Tidak makan & 46 & 12 & 120 & 12,3 & 0,000 & $3,9-40$ \\
\hline & Makan & 14 & 48 & & & & \\
\hline \multicolumn{8}{|l|}{ Lokal } \\
\hline \multirow[t]{2}{*}{ Kacang rebus } & Tidak makan & 38 & 21 & 120 & 2,88 & 0,006 & $1,3-6,1$ \\
\hline & Makan & 22 & 39 & & & & \\
\hline \multirow[t]{2}{*}{ Pisang rebus } & Tidak makan & 47 & 31 & 120 & 3,66 & 0,005 & $1,4-9,0$ \\
\hline & Makan & 13 & 29 & & & & \\
\hline \multirow[t]{2}{*}{ Buah naga } & Tidak makan & 46 & 40 & 120 & 1,5 & 0,261 & $0,7-3,3$ \\
\hline & Makan & 14 & 20 & & & & \\
\hline \multirow[t]{2}{*}{ Geblek } & Tidak makan & 42 & 29 & 120 & 2,85 & 0,017 & $1,2-6,7$ \\
\hline & Makan & 18 & 31 & & & & \\
\hline \multirow[t]{2}{*}{ Tempe koro } & Tidak makan & 44 & 37 & 120 & 1,7 & 0,183 & $0,7-3,7$ \\
\hline & Makan & 16 & 23 & & & & \\
\hline \multirow[t]{2}{*}{ Tempe Benguk } & Tidak makan & 48 & 40 & 120 & 2 & 0,109 & $0,8-4,6$ \\
\hline & Makan & 12 & 20 & & & & \\
\hline \multirow[t]{2}{*}{ Tiwul } & Tidak makan & 34 & 34 & 120 & 1 & 1 & $0,5-2$ \\
\hline & Makan & 26 & 26 & & & & \\
\hline \multirow[t]{2}{*}{ Nasi Jagung } & Tidak makan & 33 & 39 & 120 & 0,64 & 0,26 & $0,3-1,3$ \\
\hline & Makan & 27 & 21 & & & & \\
\hline \multirow[t]{2}{*}{ Bajingan } & Tidak makan & 46 & 44 & 120 & 1,2 & 0,670 & $0,5-2,7$ \\
\hline & Makan & 14 & 16 & & & & \\
\hline \multirow[t]{2}{*}{ Klepon } & Tidak makan & 39 & 31 & 120 & 1,7 & 0,149 & $0,8-3,6$ \\
\hline & Makan & 21 & 29 & & & & \\
\hline \multirow[t]{2}{*}{ Gula Semut } & Tidak makan & 37 & 25 & 120 & 2,33 & 0,033 & $1,0-5,0$ \\
\hline & Makan & 23 & 35 & & & & \\
\hline \multirow[t]{2}{*}{ Air Mineral } & Tidak makan & 50 & 41 & 120 & 2,12 & 0,079 & $0,9-4,9$ \\
\hline & Makan & 10 & 60 & & & & \\
\hline
\end{tabular}

Sumber: Data Primer, 2014

Tabel 5. Odds Ratio Menurut Jenis Makanan Keracunan Makanan

\begin{tabular}{llcccccc}
\hline \multirow{2}{*}{ Jenis Makanan } & \multirow{2}{*}{ Konsumsi } & \multicolumn{2}{c}{ Status } & \multirow{2}{*}{ Jumlah } & OR & p value & CI \\
\cline { 3 - 6 } & & Tidak Sakit & Sakit & & & & \\
\hline Sambal krecek & Tidak makan & 47 & 14 & 120 & 6,7 & 0,018 & $1,4-34,3$ \\
& Makan & 13 & 46 & & & & \\
Ayam bacem & Tidak makan & 47 & 8 & 120 & 10,4 & 0,002 & $2,3-46,7$ \\
& Makan & 13 & 52 & & & & \\
\hline
\end{tabular}

Sumber: Data Primer, 2014

pak seperti tandan buah anggur. Organisme ini Beberapa strain dapat menghasilkan racun protein gram-positif yang hidup pada suhu $18^{\circ} \mathrm{C}-40^{\circ} \mathrm{C}$. yang sangat tahan panas, yang dapat menyebab- 
kan penyakit pada manusia. Makanan yang sering dicurigai dalam kasus keracunan makanan Staphylococcus antara lain daging dan produk daging, daging unggas dan produk telur, salad seperti telur, ikan tuna, kentang, dan makaroni, produk roti seperti kue dengan isi krim, kue krim, dan coklat, roti isi dan susu dan produk susu. ${ }^{9,10}$ Makanan yang memerlukan banyak penanganan selama penyimpanan dan disimpan dalam suhu yang sedikit lebih tinggi setelah dimasak sering menjadi penyebab kasus keracunan makanan Staphylococcus ada di udara, debu, air buangan, air, susu, dan makanan atau pada peralatan makan, permukaan-permukaan di lingkungan, manusia, dan hewan. ${ }^{4,10-12}$

Manusia dan hewan merupakan sumber utama infeksi. ${ }^{2}$ Staphylococcus ada pada saluran hidung dan tenggorokan dan pada rambut serta kulit dari 50\% atau lebih individu yang sehat. . $^{3,12,13}$ Tingkat keberadaan bakteri ini bahkan lebih tinggi pada mereka yang berhubungan dengan individu yang sakit dan lingkungan rumah sakit. Walaupun pengelola makanan merupakan sumber utama kontaminasi dalam kasus-kasus keracunan makanan, peralatan dan permukaan lingkungan dapat juga menjadi sumber kontaminasi oleh Staphylococcus. $^{3}$ Keracunan pada manusia disebabkan oleh konsumsi enterotoxin yang dihasilkan oleh beberapa strain Staphylococcus di dalam makanan, ${ }^{14}$ biasanya juga dikarenakan makanan tersebut tidak dimasak pada suhu yang cukup tinggi $\left(60^{\circ} \mathrm{C}\right.$, atau lebih). ${ }^{10,15}$ Penyelidikan ini ditemukan hasil yang sejalan dengan teori serta kejadian-kejadian KLB keracunan makanan bahwa bakteri Staphylococcus memiliki masa inkubasi 1-16 jam serta secara statistik dicurigai bahwa penyebab dari keracunan adalah ayam bacem dan sambel krecek yang telah terkontaminasi.

Berdasarkan gejala yang dirasakan responden (Tabel 1) merupakan gejala kasus keracunan makanan yang diduga disebabkan oleh bakteri Staphylococcus yang mengkontaminasi makanan tersebut sebelum dikemas. Selain itu, diperoleh bahwa masa inkubasi mengarah pada bakteri Staphylococcus (Gambar 1)., ${ }^{4,5,9,10}$ Hal ini sesuai dengan teori yang dijelaskan bahwa organisme ini biasanya ditemukan pada bahan makanan yang diolah dengan tangan, baik yang tidak segera dimasak dengan baik ataupun proses pemanasan atau penyimpanan tidak tepat. ${ }^{9,10}$ Bila makanan terse- but dibiarkan pada suhu kamar untuk beberapa jam sebelum dikonsumsi, maka Staphylococcus yang memproduksi toksin akan berkembang biak dan akan memproduksi toksin tahan panas. Jenis makanan yang yang mudah terkonaminasi Staphylococcus seperti daging cincang, produk daging, sandwhich, saus salad, pastries, milk dan custard. ${ }^{5,69}$ Hampir semua KLB yang terjadi dikaitkan dengan proses pemasakan makanan dari da-ging (pemanasan kembali yang kurang benar). ${ }^{3,4}$ Spora dapat bertahan hidup pada suhu memasak normal, spora dapat tumbuh dan berkembangbiak pada saat proses pendinginan, atau pada saat penyimpanan makanan pada suhu kamar dan atau saat pemanasan yang tidak sempurna. ${ }^{2,5,10}$

\section{KESIMPULAN DAN SARAN}

Hasil yang diperoleh pada penelitian ini yaitu gejala yang dirasakan oleh responden adalah diare $(73,16 \%)$, nyeri perut $(67,10 \%)$, mual $(48,92 \%)$, dan kejang perut $(35,50 \%)$, lemas $(28,57 \%)$, pusing $(24,68 \%)$, mules $(16,88 \%)$, panas $(6,49 \%)$, tremor $(4,76 \%)$, dan muntah $(2,16 \%)$. Telah terjadi KLB keracunan makanan dengan kurva epidemik dengan tipe common source. Berdasarkan jenis kelamin kasus terbanyak adalah laki-laki yaitu 111 orang $(65,29 \%)$. Menurut golongan umur terbanyak mengalami keracunan makanan yaitu 21-45 tahun sebanyak 71 orang $(41,76 \%)$. Masa inkubasi terpendek \pm 1 jam dan masa inkubasi terpanjang adalah \pm 16 jam sehingga masa inkubasi rata-rata adalah 8 jam. Sumber keracunan diduga dari ayam bacem, dan sambel krecek ini mengandung bakteri Staphylococcus. Penjamah makanan harus lebih menjaga keamanan makanan mulai dari pengumpulan bahan makanan hingga makanan olahan siap dikonsumsi termasuk menjaga personal hygiene, serta waktu untuk menyiapkan makanan hingga dikonsumsi jangan terlalu lama karena ada probability makanan terkontaminasi jika rentang waktu terlalu lama, dan makanan yang dipanaskan harus dilakukan hingga mendidih sempurna. Sementara, untuk puskesmas dan Dinkes melakukan koordinasi lintas program dan lintas sektoral mengenai keamanan makanan di semua jenjang administrasi dan berbagi tanggung jawab.

\section{DAFTAR PUSTAKA}

1. Bres P. Tindakan Darurat Kesehatan Masya- 
rakat pada Kejadian Luar Biasa. Yogyakarta: Gadjah Mada University Press; 1995.

2. World Health Organization (WHO). Investigating Foodborne Disease Outbreaks Stage One Booklet. Geneva; 2017. pp 4-52.

3. Denayer S, Delbrassinne L, Nia Y, Botteldoorn N. Food-Borne Outbreak Investigation and Molecular Typing: High Diversity of Staphylococcus Aureus Strains and Importance of Toxin Detection. Toxins. 2017;9(12):1-13.

4. Abdou HM, Dahbi I, Akrim M, Meski FZ, V AM, et al. Outbreak Investigation of a Multipathogen Foodborne Disease in a Training Institute in Rabat, Morocco: Case-Control Study. JMIR Public Health and Surveillance. 2019;5(3):1-7.

5. Johler S, Weder D, Bridy C, Huguenin MC, Robert L, et al. Outbreak of Staphylococcal Food Poisoning among Children and Staff at a Swiss Boarding School due to Soft Cheese Made from Raw Milk. Journal of Dairy Science. 2015;98(5):2944-2948.

6. Ercoli L, Gallina S, Nia Y, Auvray F, Primavilla $\mathrm{S}$, et al. Investigation of a Staphylococcal Food Poisoning Outbreak from a Chantilly Cream Desser, in Umbia (Italy). Foodborne Pathogens and Disease. 2017;14(7):407-413.

7. WHO. Foodborne Diseases in the WHOSouthEast Asia Region. [Report]. World Health Organization; 2015. Available at: https://apps. who.int/iris/handle/10665/327655

8. BPOM RI. Laporan Tahunan. Jakarta: Badan Pengawas Obat dan Makanan RI; 2018. Available at: https://www.pom.go.id/new/admin/dat/20180710/Laporan Tahunan BPOM 2017.pdf
9. Tong SYC, Davis JS, Eichenberger E, Holland TL, Fowler VG. Staphylococcus Aureus Infections: Epidemiology, Pathophysiology, Clinical Manifestations, and Management. Clinical Microbiology Reviews. 2015;28(3):603-661.

10. Taylor TA, Unakal CG. Staphylococcus Aureus. [Online]. NCBI; 2019. Available at: https://www.ncbi.nlm.nih.gov/books/ NBK441868/

11. Mossong J, Decruyenaere F, Moris G, Ragimbeau C, Olinger CM, Johler S, et al. Investigation of a Staphylococcal Food Poisoning Outbreak Combining Case-Control, Traditional Typing and Whole Genome Sequencing Methods, Luxembourg, June 2014. Euro Surveillance. 2015;20(45):1-7.

12. Chin J. Control of Communicable Diseases Manual. Washington: American Public Health Association; 2000. pp 232-234.

13. Lemeshow HJS, W D, Klar J, Lwanga SK. Part 1: Statistical Methods for Sample Size Determination. Adequacy Sample Size Health Studies [Online]. World Health Organization; 1990. Available at: http://apps.who.int/iris/ bitstream/10665/41607/1/0471925179_eng. pdf?ua $=1$

14. Kadariya J, Smith TC, Thapaliya D. Staphylococcus Aureus and Staphylococcal FoodBorne Disease: an Ongoing Challenge in Public Health. Hindawi Publishing Corporation. 2014;1-9.

15. Manfredi EA, Rivas M. Brote de Intoxicación Alimentaria en un Jardín de Infantes de la Provincia de Buenos Aires. Revista Argentina de Microbiologia. 2019;51(4):354-358. 